\title{
Examining the Effect of Exchange Rate and Overseas Employment on Remittances: An Evidence from Bangladesh
}

\author{
Mohammad Raselar Rahman, Md. Muhaiminul Islam Selim, Md. AhsanUlHaque, \\ Dilruba Yesmin Smrity, Md. Shafiqul Islam*
}

Department of Economics, Noakhali Science and Technology University, Noakhali, Bangladesh

Email: *shafique24253@gmail.com

How to cite this paper: Rahman, M.R., Selim, Md.M.I., AhsanUlHaque, Md., Smrity, D.Y. and Islam, Md.S. (2019) Examining the Effect of Exchange Rate and Overseas Employment on Remittances: An Evidence from Bangladesh. Theoretical Economics Letters, 9, 2593-2605.

https://doi.org/10.4236/tel.2019.97163

Received: May 18, 2019

Accepted: October 13, 2019

Published: October 16, 2019

Copyright $\odot 2019$ by author(s) and Scientific Research Publishing Inc. This work is licensed under the Creative Commons Attribution International License (CC BY 4.0).

http://creativecommons.org/licenses/by/4.0/

(c) (i) Open Access

\begin{abstract}
In Bangladesh, remittances have been increasing from its preceding period. It can prevent a balance of payment crises as well as it has a positive impact on the economy of Bangladesh. In this paper, an attempt is made to analyse the effect of exchange rate and overseas employment on remittances in the Bangladesh economy using time series econometric techniques, particularly, vector error correction model to investigate the long-run and short-run relationship among variables where deposit interest rate and global oil price have been used as control variable. The findings show that there is a significant effect of the exchange rate and overseas employment on remittance. The results also show that depreciation of the domestic currency causes remittances to increase in the consequences of Bangladesh, and an increase in overseas employment also has a significant effect on remittances. In the short run, global oil and deposit interest rate can affect remittances because the short-run lagged coefficient of deposit interest rate is significant. An appropriate policy can be taken regarding exchange rate considering the importing cost in mind to inflow remittances in Bangladesh.
\end{abstract}

\section{Keywords}

Bangladesh, Remittances, Deposit Interest Rate, Overseas Employment, Global Oil Price, Co-Integration, Vector Error Correction Model (VECM)

\section{Introduction}

Developing nations which mostly rely on remittance seems to have governments with less stability and are reluctant to repay the debt or not go into default. While organizations such as the World Bank, International monetary fund 
(IMF) can provide funding, these funds often come with strings attached. For governments in the developing country, this may be too much of a step on sovereignty, primarily it is a thread for holding power. Countries expend fund for development using remittances in their own way. Using these funds efficiently, developing nations must adopt some policies that help smart and stable growth, and the growth is not solely concentrated in the cities. It also diversified from urban to the remote area. Bangladesh is a developing country. It has a higher population than its resources. In the consequences of the developing country in Bangladesh, there exists a surplus of labor. There have no sufficient industries for this excess labor, and also the wage rate of the labor is not satisfactory.

This is why people of Bangladesh are migrating to developed countries. From the very beginning of the Bangladesh independence war, people started to migrate abroad in quest of a better life also for better earnings. Political unrest is also another reason to migrate poor to a rich country. According to the estimation of the ministry of expatriates and welfare (2018), there are $11,811,970$ people of Bangladesh who are working abroad, and it reflects $7.1 \%$ of the total population. In 2017 Bangladesh received an amount of 13,526.84 million USD remittance. Remittance is the income of the individuals of a receiver country.

Figure 1 shows that there is an increasing trend of the remittance inflow in Bangladesh. In 2015, Bangladesh received the highest remittances inflow in the country. In 2016 to 2017 remittances declined from its preceding period, the reason behind this condition is when remitters are sending their money to the home they use the informal channel, as well as the anarchy among middle east countries. The increasing tenor of overseas employment for the Bangladesh economy is clearly apparent. Remittances have become a major source of foreign exchange earnings, then the second only to ready-made garments. It contributed $61 \%$ of the recent foreign exchange reserve buildup in FY-(2014-2015). Overseas employment itself has a strong position and represents over one-fifth of the annual addition to the country's total labor force. Remittance contributes to the growth of the gross domestic product (GDP) of Bangladesh. It helps people to get money directly in hand, and the individuals can spend this money on areas like education and healthcare which may not be possible with official aid; the

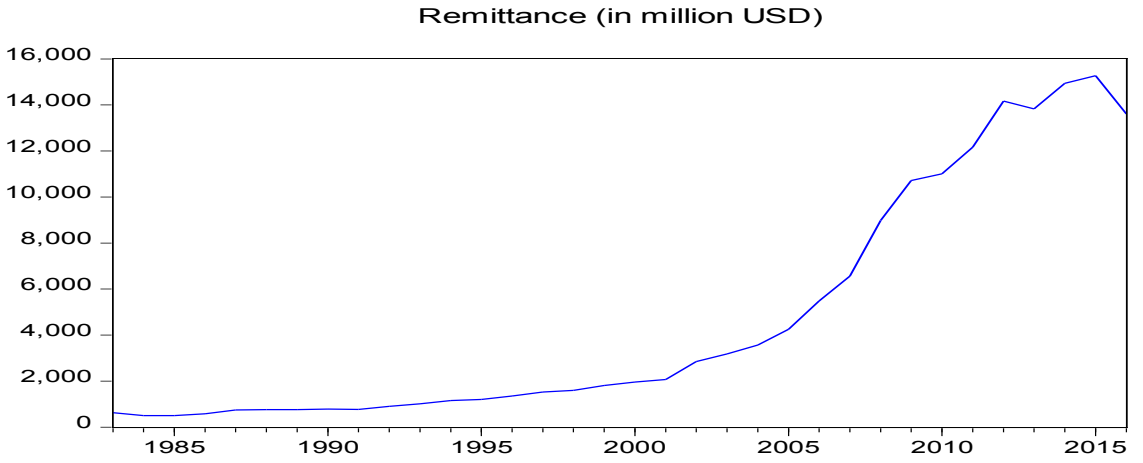

Figure 1. Remittance inflow in Bangladesh (FY-1983-2016). Data source: Bangladesh Bank (2018). 
consumer has considerably more sovereignty to use that money; the sender is confident that the money will be used effectively which might not be the case with official aid. Remittance helps maintain a country's external balance as well as, it has a more significant impact on education, socio-economic development, and the wellbeing of the population which in turns ensures the prosperity of the nation. An empirical analysis (P. Acosta, P. Fajnzylber and J.H. Lopez, [1]) indicates that at the country level, higher remittances inflows tend to lower poverty indicators and higher growth rates. In a micro sense, remittance plays an anti-poverty role due to increase in income, contributing to higher investment in education and healthcare remittance works as a means for investment. In a broader sense, if the remittances transferred through formal channels, it works as a source of foreign exchange reserve. Remittances provide incentives to increase in consumption, demand for local goods or services, and job creation, remittance stimulates aggregate demand and hence economic growth. Bilateral trade in home and host countries is also increased with the help of it. Remittance increases the reserve of the country, which is very important to feed up the Balance of payment (BoP). Remittance also affects price level in the presence of a weaker monetary control. As remittances are very important phenomena of a country, so its influential variables are also important. Overseas employment and exchange rate etc. has a significant and vital role in boosting the remittance flow. Exchange rate fluctuation and domestic currency devaluation attract the remitters and it has a greater impact on the remittance flow to the receiver country. Examining the character of the determinants that influence the remittance is beneficial for the beneficiary country.

The determinants of the remittance are the apple of discord to the researchers because of the remittance influences to the GDP, socioeconomic development and also the standard of living as well as it makes financially solvent a family. Overall, remittance is the foremost external source of income which has a vast influence on the economy of a country. For the better policy adaptation to increase the volume of the remittances, there must need empirical analysis to know the character of the endogenous variable say, remittance. This paper organized as follows, the previous study of the fact. Formulating the methodology of the study and collecting the relevant data to attach on the model. Finally, we examined the effect using that data and run some necessary test to get the expected result.

\section{Literature Review}

This paper uses secondary time series data of Bangladesh. Paper aims to examine the effect of the exchange rate and overseas employment on remittances in Bangladesh. The impact of the exchange rate and overseas employment on remittances was not examined simultaneously in international research. Nahidakhter and Kamrul Islam [2] they found the empirical outcomes which reveal that there is a significant relationship between growth in remittances and different out- 
come variables in the economy with a positive impact on poverty, household income, and financial inclusion. Their results indicate that both domestic and international remittances have a positive impact on poverty alleviation, and these results are statistically significant. International migration and remittance supplies are important pathways out of poverty for poor households. They used the Logit regression model as the primary analytical tool for this purpose. Jamal Bouoiyour, RefkSelmia, and Amal Miftah [3] examined the economic impact of migrant' remittances, expected to have a countercyclical behavior. They used two estimates for two different periods: the first one corresponds to the period before the Arab Spring spanning between 1990:Q1 and 2010:Q4 (i.e., 85 observations) and the second one refers to an extended period (prior to and post Arab Spring event) that spans between 1990:Q1 and 2015:Q3 (i.e., 104 observation). Their results revealed that before the Arab Spring, the impacts of remittances on growth and consumption seem negative and positive, respectively, while they varyingly influence local investment. These three relationships held in the short-run. By considering the period surrounding the 2011 uprisings, the investment effect of remittances becomes negative and weak in the short- and medium-run, whereas positive and strong remittances' impacts on growth and consumption are found in the long term. Ebenezer A. Olubuyi and Kubrat O. Kehinde [4] used a simple theoretical ordinary least squares (OLS)) model, where the data ranges from FY (1980-2013). They discovered that the real exchange rate impacted negatively on remittances, which implied an expected depreciation of the real exchange rate that signals adverse economic conditions back home dwarfs remittance inflows. Chnaina and Makhlouf [5] showed that an increase in worker's remittances by one percentage point of GDP resulting in an appreciation of Tunisia's real exchange rate by 0.39 percent. There are other channels through which remittances could affect growth, namely human capital and labor supply. Kanchan Datta and Bimal Sarkar [6] found that the receivers of remittance usually depend highly on the easy money, which causes them to reduce their efforts and their participation in the labor market, which would affect economic growth negatively in the context of Bangladesh. They attempted to analyze the impact of remittances on economic growth in the Bangladesh economy, using time series econometric techniques, specifically, the autoregressive distributed lag (ARDL) framework. Ripon Roy and Md. Mokhlesur Rahman [7] worked on Remittance-Inflation Relationship in Bangladesh. They used monthly data over the time period July 2003-July 2013 (post-floating exchange rate scenario) and empirically tested that inflation, as well as food inflation in Bangladesh, is a cause of growing remittance. They used the co-integration technique to determine the long-run relationship between remittances and inflation also applied a Vector Error Correction Model (VECM) approach for estimating the direction, extent, and significance of the relationship. They found that the results of both the models show that remittance inflows cause inflationary pressure in Bangladesh while the responsiveness of food inflation is almost two and a 
half times higher than general inflation. Using a theoretical model and panel vector autoregression techniques, Ball, Lopez, and Reyes [8] tested the same effect. They used yearly as well as quarterly data for 21 emerging countries. Their model predicts that remittances temporarily increase the domestic money supply and inflation under a fixed exchange rate regime while temporarily generate no change in the money supply, decrease inflation and appreciate the real exchange rate under a flexible exchange rate regime. Adebayo Adedokun [9] used ARIMA model to estimates the size of expected remittances into the economy over the coming decade of Nigeria. The paper revealed that the remittances into the economy in the coming years would grow at an average 6\% per year and the percentage of GDP expected to reach about 11.4 percent by 2019. The study examines the remittances as a percentage of GDP; as such, REMPGD symbolizes the rate of remittances to GDP; it uses time-series data from 1977 to 2009. Barajas and Fayads [10] indicated that remittances tend to appreciate the real exchange rate (RER) but only under certain country-specific economic circumstances. More specifically, Barajas [10] concluded that only countries with more open capital accounts and low levels of trade are likely to experiences RER appreciation associated with increased levels of remittances. The most stunning revelation of Fayad's [10] analysis, concerning those previously mentioned, is that any empirical study on the RER and remittances must take into account the degree of openness of the country's capital account and its level of trade with the rest of the world. However, Reinhart and Rogoff [11] showed that the effect of remittance inflows would be a rising price level and an appreciation of the exchange rate under a flexible exchange rate regime. BurcuÖzcan [12] addressed an empirical analysis of the relationship between workers' remittances and the real exchange rate in 10 developing countries. They used annual data from ten developing (Argentina, Fiji, Mexico, Sri Lanka, Sudan, Philippine, Lesotho, Bolivia, Benin, Madagascar) countries in the 1980-2009 period. Using Pedroni's panel co-integration tests and fully modified ordinary least squares (FMOLS) estimator, they found no support that workers' remittances generate Dutch disease effect in these countries. Also, his results suggest that international remittances have the potential to strengthen these countries' export structures, if suitable policy tools support them, as more liberalized trade regimes. Paul and Das [13] found a long-run positive relationship between remittances and GDP, but that there was no evidence on remittance-led growth in the short run. They worked on a relatively liberalized regime from 1979 to 2009. To generate the analysis, they used the VECM method. Humberto Lopez, Luis Molina, and Maurizio Bussolo [14] found that remittances impact positively on a good number of development indicators of recipient countries. When flows are too large compared to the size of the recipient economies, like those observed in several Latin American countries, they may also bring several undesired problems. They explore the empirical evidence regarding the impact of remittances on the real exchange rate. Their findings suggest that indeed, remittances appear to lead to a signifi- 
cant real exchange rate appreciation. They also explore policy options that may somewhat offset the observed effect. Acosta, Lartey, and Mandelman [15] found the effects of remittances on the real exchange rate using an unbalanced panel data set for 109 developing with disaggregated sectoral data and transitional countries for the period 1990-2003. Analysis was done using an OLS country fixed-effects model and generalized method of moments (GMM) exposed that GDP per capita, the terms of trade index, and GDP growth resulted in real exchange rate appreciation and they are statistically significant at the $10 \%$ level. As well as, it was found that trade openness is statistically insignificant. Specifically, they explored that an increase in remittances in developing economies results in increased spending, which results in an increase in the price of non-tradables. Additionally, the increase in the price of non-tradables also results in resource movement, thus reducing productivity in the manufacturing sector. Consequently, this leads to real exchange rate appreciation. Farhana Akhter and $\mathrm{Nu}-$ shrat Faruqui [16] compared the performance of previous and current exchange rate regime with selected south Asian countries and analyses and discusses how macroeconomic variables influenced exchange rate. For these analyses four major independent variables have been considered i.e. export amount, remittance, import amount and foreign currency reserve and independent variable is exchange rate. For evaluating the relationship and nature of relationship the researchers used correlation and regression analysis and found that macroeconomic variables significantly influenced the exchange rate and adopting the floating exchange rate regime Bangladesh experienced positive impacts on macroeconomic development of the country. Amuedo-Dorantes and Pozo [17] investigate the impact of worker's remittances on the real exchange rate on 13 Latin America and Caribbean economies. They used fixed-effect OLS taking into consideration the instrumental variables to account for the possibility of dependability. The results postulated the fact that remittances have the ability to appreciate the real exchange rate in the recipient economy. It was explored that "a doubling of remittances to GDP ratio would lead to a real exchange rate appreciation of above $22 \%$ ". Foreign aid was not statistically significant in this model for exchange rate determination.

Most of the literature revealed that there is a negative relationship between remittances and exchange rate. In the former study, it is evident that all the researcher investigated the remittance impacts on the exchange rate. But we do not find appropriate evidence that investigate the impact of overseas employment and exchange rate on remittances in a precise way. So, in our analysis, we step forward and investigate the dominance of exchange rate and overseas employment on the remittance. And this exclusivity makes an impression to study more. Also, some authors choose the VECM method to investigate the relationship. In this paper, we seek to fill the empirical gap with the expectation that the outcome of the investigation will be helpful to establish an appropriate exchange rate and policy that will help to boost the remittance inflow. 


\section{Methodology}

This is a time series analysis based on vector error correction model to investigate the effect of the exchange rate and overseas employment on remittances in the context of Bangladesh. We use the co-integration [18] method as well as the vector error correction model (VECM) [19]. We also check several diagnostics among data named, heteroscedasticity, autocorrelation, Jarque-Bera [20] for normality assumption of residuals, unit root test is also used to find out the stationarity condition of the mean and variance of the data over time. The functional form of the model is,

$$
\text { remit }=f \text { (goil, oemp, exrate, DIR etc.) }
$$

where, remit is the amount of remittances inflow from advanced countries to Bangladesh, oemp and DIR represent Bangladeshi's overseas employment and deposit interest rate respectively, exrate is the exchange rate while goil stands for global oil price variables affecting remittances. Thus the remittance is a function of global oil price, deposit interest rate, exchange rate, overseas employment.

The log linearmodel [21] for the analysis is

$$
\ln \text { remit }_{t}=\beta_{0}+\beta_{1} \ln \text { oemp }_{t}+\beta_{2} \ln \text { exrate }_{t}+\beta_{3} \ln \text { goil }_{t}+\beta_{4} \mathrm{DIRt}+u_{t-1}
$$

Here " $t$ " is the time and $\beta_{0}, \beta_{1}, \beta_{2}, \beta_{3}, \beta_{4}$, are the elasticity of the variables, also remit, oemp, exrate, goil, DIR is the variables respectively. This is a log-linear model. The superiority of the model is we can estimate the elasticity remittances with respect to other independent variables.

As the VECM shows us the long-run relationship among variables and the short-run adjustment coefficient so we perform the VECM. Before that we check the unit root of the variables, and also ensure that there is at least one co-integrating equation to run the VECM.

\subsection{Vector Error Correction Model (VECM) [19]}

Vector error correcting model is applied when there is at least one co-integrating equation between independent and dependent variables. This analysis shows the long run and short run dynamic relationship using generalized least square (GLS) and restricted and this restriction make a strong estimation. Here the model is

$$
\begin{gathered}
\Delta \text { remit }_{t}=\beta_{0}+\sum_{i=1}^{n} \beta_{i} \Delta \text { remit }_{t-i}+\sum_{i=0}^{n} \alpha_{i} \Delta \text { oemp }_{t-i}+\sum_{i=0}^{n} \gamma_{i} \Delta \text { exrate }_{t-i} \\
+\sum_{i=0}^{n} \delta_{i} \Delta \operatorname{DIR}_{t-i}+\sum_{i=0}^{n} \mu_{i} \Delta \text { goil }_{t-i}+\varphi z_{t-1}+\mu_{t} \\
\text { remit }_{t}=\beta_{0}+\beta_{1} \text { oemp }_{t}+\beta_{2} \text { exrate }_{t}+\beta_{3} \mathrm{GIR}_{t}+\beta_{4}+\varepsilon_{t} \\
z_{t-1}=\mathrm{ECT}_{t-1}=\text { remit }_{t}-\beta_{0}-\beta_{1} \text { goil }_{t-1}-\beta_{2} \text { exrate }_{t-1}-\beta_{3} \mathrm{DIR}_{t-1}-\beta_{4} \text { oemp }_{t-1}
\end{gathered}
$$

In this model, $\Delta$ as the differencing notation and $u_{t}$ as the white noise stochastic disturbance term. The term, error-correction, means that last period deviation from long-run equilibrium (the error) influences the short-run dynamics of the dependent variables. Thus, the coefficient of ECM is speed of adjustment, because it measures the speed at which dependent variable returns to equili- 
brium after a change in independent variable.

\subsection{Data Collection}

For the convenience of the study we collect secondary data from different source. We collect the data of remittance inflow in million USD in Bangladesh, the overseas employment each year from the ministry of expatriate's welfare and overseas employment [22] website. We also collect the deposit interest rate and exchange rate from world bank [23] database' the global oil price dollar per barrel data from the source of Fred St. Louis [24] database. All data are collected in yearly format and it ranges from FY-1990-2016.

\subsection{Empirical Results}

From Table 1 it is evident that three tests (autocorrelation, Homoscedasticity, Normality assumption) null hypothesis are accepted. Because the p-value is more than 5\% level of significance. So it can be concluded that there is no serial correlation, the data are normally distributed, and the variance is homoscedastic.

\subsection{Unit root Test [27]}

All the variables are tested whether the variable has stationarity property at I(1). This is tested through most popular unit root process (Table 2).

Here the null hypothesis is,

$\mathrm{H}_{0}=$ The variables have a unit root

$\mathrm{H}_{\mathrm{A}}=$ The variables don't have a unit root.

The decision is "at level" the p value is higher than the $5 \%$ significance level, and the null hypothesis is accepted, so all the variable has a unit root at the level. But in the 1st difference p-value of all variables are not higher than $5 \%$ level of significance. So the null hypothesis is rejected. And the data has stationarity at 1 st difference. It means that at first difference, the mean and variance of the variable are constant over time. Thus, all variables are integrated into order 1, I(1). This implies that we need to check for the presence of co-integration relationships among the variables. The co-integration test results Table 2 , indicate 2 co-integrating relations in the equation. Lag length was determined using the Akaike Information Criterion [28] (AIC) and that is lag 2.

Table 1. Test for model adequacy (normality, serial correlation, heteroscedasticity).

\begin{tabular}{|c|c|c|c|c|c|}
\hline Theory & Name of the test & Null Hypothesis $\mathrm{H}_{0}$ & Test statistic & Prob. & Decisions \\
\hline $\begin{array}{l}\text { Normality } \\
\text { Assumption of Residuals }\end{array}$ & Jarque-Bera test [20] & $\begin{array}{c}\text { Residuals are normally } \\
\text { distributed }\end{array}$ & 0.810 & 0.667 & $\begin{array}{c}\mathrm{H}_{0} \text { cannot be rejected at } 1 \%, \\
5 \% \text { and } 10 \% \text { level of } \\
\text { significance }\end{array}$ \\
\hline Serial Correlation & $\begin{array}{c}\text { Breusch-Godfrey Serial } \\
\text { Correlation LM [25] test (lag 2) }\end{array}$ & $\begin{array}{c}\text { There is no serial } \\
\text { correlation }\end{array}$ & 3.089 & 0.073 & $\begin{array}{c}\mathrm{H}_{0} \text { cannot be rejected at } 1 \% \text {, } \\
5 \% \text { level of significance }\end{array}$ \\
\hline
\end{tabular}

Source: Author's own calculation by E-views 9.0 Student Lite Version. 
Table 2. Unit root test including intercept term.

\begin{tabular}{ccccccccc}
\hline $\begin{array}{c}\text { Variable } \\
\text { Name }\end{array}$ & \multicolumn{3}{c}{ At level } & & \multicolumn{3}{c}{ At $1^{\text {st }}$ difference } \\
\hline & $\begin{array}{c}\text { ADF test } \\
\text { statistics }\end{array}$ & $\begin{array}{c}\text { Lag } \\
\text { length }\end{array}$ & $\begin{array}{c}5 \% \text { critical } \\
\text { value }\end{array}$ & P value & $\begin{array}{c}\text { ADF } \\
\text { test statistics Length }\end{array}$ & $\begin{array}{c}\text { Lag } \\
5 \% \text { critical } \\
\text { value }\end{array}$ & P value \\
\hline lnremit & 0.415 & 0 & -2.954 & 0.981 & -4.593 & 0 & -2.957 & 0.0009 \\
lnemp & -0.986 & 2 & -2.960 & 0.746 & -5.781 & 1 & -2.960 & 0.0000 \\
lnerate & -2.207 & 0 & -2.954 & 0.208 & -4.128 & 0 & -2.957 & 0.003 \\
DIR & -2.469 & 1 & -2.957 & 0.132 & -4.353 & 2 & -2.964 & 0.0018 \\
lngoil & -1.051 & 0 & -2.954 & 0.723 & -5.481 & 0 & -2.957 & 0.0001 \\
\hline
\end{tabular}

Source: Author's own Calculation by e-views 9.5 student lite version.

\subsection{Co-Integration Test (Table 3)}

Table 3. Johansen co-integration test [29]: unrestricted co-integration rank test (trace).

\begin{tabular}{ccccc}
\hline Hypothesized No. of CE(s) & Eigen value & Trace statistic & 0.05 Critical value & Prob. $^{* *}$ \\
\hline None $^{*}$ & 0.9919 & 188.812 & 69.81889 & 0.0000 \\
At most $1^{*}$ & 0.8521 & 73.142 & 47.85613 & 0.0000 \\
At most 2 & 0.5068 & 27.261 & 29.79707 & 0.0954 \\
At most 3 & 0.2528 & 10.292 & 15.49471 & 0.2589 \\
At most 4 & 0.1283 & 3.2972 & 3.841466 & 0.0694 \\
\hline
\end{tabular}

Source: Author's own calculation by E-views 9.0 Student Lite Version. Trace test indicates 2 co-integration equations at the 0.05 level, ${ }^{*}$ denotes rejection of the null hypothesis of existing co-integration. ${ }^{* *}$ Mackinnon (1991) p-values Lag Intervals at first difference: $1-2$.

There exists two co-integrating equation. So it identifies a situation where non stationary time series are bound together in such a way that they cannot deviate from some equilibrium in the long term. So VECM is applicable there.

\subsection{Estimation with the Help of VECM}

Having established two co-integration relationship among the variables, a VECM was estimated, based on rank $r=1$ and two lagged differences, for the 1983-2016 sample period. All lag lengths were determined by minimizing the information criteria of Akaike Information Criterion [28] (AIC). The estimated, long-run co-integration relationship is presented in Table 4.

Co-efficient indicate significance at the $1 \%$ level. In Table 4 shows standard errors, \{\} show the $t$-statistics and [] show the critical values, and $\left(^{*}\right)$ for $10 \%$, $\left({ }^{*}\right)$ for $5 \%$ level of significance. The null hypothesis of zero coefficient will be rejected if the condition of tcal $>$ tcritical is fulfilled.

From Table 4, our long run regression equation is

$$
\begin{aligned}
\ln \text { remit }_{t-1}= & -3.161+0.114 \ln \text { oemp }_{t-1}+1.994 \ln \text { exrate }_{t-1} \\
& +0.603 \operatorname{lngoil}_{t-1}-0.036 \mathrm{DIR}_{t-1}+u_{t-1}
\end{aligned}
$$


Table 4. Estimated long-run co-integration vector.

\begin{tabular}{cccccc}
\hline Lnremit $_{t-1}$ & Lnoemp $_{t-1}$ & Lnexrate $_{t-1}$ & Lngoil $_{t-1}$ & DIR $_{t-1}$ & C \\
\hline 1.0000 & -0.114 & -1.994 & -0.604 & 0.036 & 3.161 \\
& $(0.015)$ & $(0.023)$ & $(0.010)$ & $(0.003)$ & \\
& $\{-7.731\}$ & $\{-85.171\}$ & $\{-58.892\}$ & $\{13.263\}$ & \\
& {$\left[1.697^{\star}\right]$} & {$\left[2.042^{\star *}\right]$} & {$\left[2.042^{\star *}\right]$} & {$\left[2.042^{\star *}\right]$} & \\
\hline
\end{tabular}

Source: Author's own calculation by E-views 9.0 Student Lite Version.

Table 5. Short run speed of adjustment.

\begin{tabular}{ccccc}
\hline & Coefficient & Std. Error & t-statistic & Prob. \\
\hline$C_{1}^{* * *}$ & -0.856883 & 0.184870 & -4.635057 & 0.0006 \\
$\mathrm{C}_{2}$ & -0.166393 & 0.212970 & -0.781297 & 0.4498 \\
$\mathrm{C}_{3}$ & 0.000325 & 0.189936 & 0.001711 & 0.9987 \\
$\mathrm{C}_{4}^{* *}$ & -0.3418855 & 0.110513 & -2.885220 & 0.0137 \\
$\mathrm{C}_{5}^{* *}$ & -0.280187 & 0108208 & -2.589336 & 0.0237 \\
$\mathrm{C}_{6}$ & -0.389465 & 0.483313 & -0.805824 & 0.4363 \\
$\mathrm{C}_{7}$ & -0.737908 & 0.511490 & -1.442663 & 0.1747 \\
$\mathrm{C}_{8}$ & -0.037669 & 0.053889 & -0.699014 & 0.4979 \\
$\mathrm{C}_{9}$ & -0.072367 & 0.051955 & -1.392868 & 0.1889 \\
$\mathrm{C}_{10}{ }^{* *}$ & 0.040586 & 0.015488 & 2.620412 & 0.0224 \\
$\mathrm{C}_{11}$ & -0.007376 & 0.013962 & -0.528295 & 0.6069 \\
$\mathrm{C}_{12}{ }^{* * *}$ & 0.215938 & 0.048422 & 4.459527 & 0.0008 \\
\hline
\end{tabular}

Source: Author calculation by E-views 9.0 Student Lite Version.

From the error correction model in the above equation shows that overseas employment is positively significant to increase the volume of remittance. Global oil price increases the remittance. Here also the exchange rate increases the remittance. This result is consistent with the other research findings, where the 1 percent change of global oil price increases remittance by $0.603 \%$ and again the 1 percent change in overseas employment increases the remittances by $0.114 \%$ the 1 percent change in exchange rate increases remittances by $1.994 \%$ finally the 1 percent interest rate change can cause the $0.0395 \%$ decrease the remittance. Considering the speed of adjustment parameters, the error correction term is said to be significant in the equation, except the goil and emp. This implies that for any deviation from the long-run equilibrium, these two variables are unresponsive in reverting the relationship to equilibrium. (Table 5)

The test statistics are significant if $\mathrm{p}$ values are less than $0.01\left(^{* * *}\right)$ or less than $\left.0.05{ }^{* *}\right)$ or less than $\left.0.10{ }^{*}\right)$.

Here the equation is,

$\mathrm{D}(\mathrm{LNREMIT})=\mathrm{C}(1)^{*}\left(\operatorname{LNREMIT}(-1)-0.603812^{\star} \operatorname{LNGOIL}(-1)-\right.$ 


$$
\begin{aligned}
& 1.993731^{\star} \operatorname{LNERATE}(-1)-0.113835^{\star} \operatorname{LNEMP}(-1)+ \\
& \left.0.0359^{\star} \mathrm{DIR}(-1)+3.1611\right)+\mathrm{C}(2)^{\star} \mathrm{D}(\operatorname{LNREMIT}(-1))+ \\
& \mathrm{C}(3)^{\star} \mathrm{D}(\operatorname{LNREMIT}(-2))+\mathrm{C}(4)^{*} \mathrm{D}(\operatorname{LNGOIL}(-1))+ \\
& \mathrm{C}(5)^{\star} \mathrm{D}(\operatorname{LNGOIL}(-2))+\mathrm{C}(6)^{\star} \mathrm{D}(\operatorname{LNERATE}(-1))+ \\
& \mathrm{C}(7)^{\star} \mathrm{D}(\operatorname{LNERATE}(-2))+\mathrm{C}(8)^{\star} \mathrm{D}(\operatorname{LNEMP}(-1))+ \\
& \mathrm{C}(9)^{\star} \mathrm{D}(\operatorname{LNEMP}(-2))+\mathrm{C}(10)^{*} \mathrm{D}(\mathrm{DIR}(-1))+ \\
& \mathrm{C}(11)^{\star} \mathrm{D}(\mathrm{DIR}(-2))+\mathrm{C}(12)
\end{aligned}
$$

$\mathrm{C} 1$ is the error correction term which is negative here and also significant. Negative sign means the short term shock is restoring to the equilibrium at the speed of $85.68 \%$. The estimates indicate that in the case of a discrepancy in one lagged period deviation from the long-run equilibrium, the most effective response to restore the system to equilibrium are global oil price and deposit interest rate. The short-run relationships further show that remittance is significantly explained by its own first lag, while global oil price and deposit interest rate are significant and coefficients are also negative in all lags where overseas employment and exchange rate are insignificant in all lags.

\section{Conclusion and Recommendations}

Remittances are playing an emerging role in the economies of many countries. It contributes to economic growth and to the livelihoods of those countries where Bangladesh is one of them. Nowadays, remittance has an essential influence on the economy of Bangladesh. Moreover, Bangladesh has to embark on necessary reforms and adopt policies relevant for repositioning the economy before it can enjoy the benefits associated with remittance. And also a more functional institutional arrangement needs to be established to guarantee the effective monitoring and supervision remittance inflow in the economy. To increase its volume more than before the government should take the initiative such as ensuring the trained worker abroad. The government should also take necessary steps to stop the illegal entry of foreign earning. Mobile Banking, Hundis is an illegal channel so it should be prevented. Money transfer fee should be smooth and cost-free. In our analysis, the estimated model suggests that global oil price, overseas employment, exchange rate as well as the deposit interest rate positively influence the remittances during the period under investigation. Our findings, including those of others in the literature review, relay some vital tendencies in developing countries. Exchange rate and deposit interest rate should be volatile to attract remittances. But there is a problem that Bangladesh is an importing country than exporting, so the depreciation of the exchange rate can cause an increase of importing cost. So the matter should bear in mind while taking policy. Effective and trained workers are also necessary for the satisfactory inflow of remittances in Bangladesh. Necessary steps can also be taken to increase the impact of overseas employment and exchange rate on remittances in the long term. Further study can take place to forecast the remittances flow to the receiver country. 


\section{Conflicts of Interest}

The authors declare no conflicts of interest regarding the publication of this paper.

\section{References}

[1] Acosta, P., Fajnzylber, P. and Lopez, J.H. (2007) The Impact of Remittances on Poverty and Human Capital: Evidence From Latin American Household Surveys. World Bank Policy Research Working Paper 4247.

[2] Akhter, N. and Islam, K. (2019) The Impact of Migration and Migrant Remittances on Household Poverty in Banglades. Asian Development Perspectives, 10, 43-59.

[3] Jamal, B., Selmia, R. and Amal, M. (2018) Relationship between Remittances and Macroeconomic Variables in Times of Political and Social Upheaval: Evidence from Tunisia's Arab Spring.

[4] Olubuyi, E.A. and Kubrat (2015) Does Exchange Rate Affect Remittances in Nigeria? The Review of Finance and Banking, 7, 31-45.

[5] Chnaina, K. and Makhlouf, F. (2015) Impact des Transferts de Fonds sur le Taux de Change Réel Effectifen Tunisie. African Development Review, 27, 145-160. https://doi.org/10.1111/1467-8268.12130

[6] Kanchan, D. and Bimal, S. (2014) Relationship between Remittances and Economic Growth in Bangladesh: An Econometric Study. Bangladesh Development Research Center (BDRC).

[7] Ripon, R. and Mokhlesur, R. (2014) An Empirical Analysis of Remittance-Inflation Relationship in Bangladesh: Post-Floating Exchange Rate Scenario. http://mpra.ub.uni-muenchen.de/55190/

[8] Ball, C., Lopez, C. and Reyes, J. (2013) Remittances, Inflation and Exchange Rate Regimes in Small Open Economies. World Economy.

https://doi.org/10.2139/ssrn.1119318

[9] Adebayo, A. (2013) Forecasting Remittances as a Major Source of Foreign Income to Nigeria: Evidence from ARIMA Model. European Journal of Humanities and Social Sciences, 24.

[10] Barajas, A., Chami, R., Hakura, D.S. and Monteil, P. (2010) Workers' Remittances and the Equilibrium Real Exchange Rate: Theory and Evidence. International Monetary Fund. Working Paper.

[11] Reinhart, C. and Rogoff, K. (2004) The Modern History of Exchange Rate Arrangements: A Reinterpretation. Quarterly Journal of Economics, 119, 1-48. https://doi.org/10.1162/003355304772839515

[12] Burcu, Ö. (2011) The Relationship between Workers' Remittances and Real Exchange Rate in Developing Countries. International Research Journal of Finance and Economics, 80.

[13] Paul, B.P. and Anupam, D. (2011) The Remittance-GDP Relationship in the Liberalized Regime of Bangladesh: Co-Integration and Innovation Accounting. Theoretical and Applied Economics, 18, 41-60.

[14] Humberto, L., Luis, M. and Maurizio, B. (2007) World Bank Policy Research. Working Paper.

[15] Acosta, P., Lartey, E. and Mandelman, F. (2008) Remittances, Exchange Rate Regimes, and the Dutch Disease: A Panel Data Analysis. Federal Reserve Bank of Atlanta, Working Paper. https://doi.org/10.2139/ssrn.1109206 
[16] Akhter, F. and Faruqui, N. (2015) Effects of Macroeconomic Variables on Exchange Rates in Bangladesh International. Journal of Scientific \& Engineering Research, 6, 1028-1034.

[17] Amuedo, D.C. and Pozo, S. (2004) Workers' Remittances and the Real Exchange Rate: A Paradox of Gifts. World Development, 32, 1407-1417. https://doi.org/10.1016/j.worlddev.2004.02.004

[18] Engle, R.F. and Granger, C.W.J. (1987) Co-Integration and Error Correction: Representation, Estimation and Testing. Econometrica, 55, 251-276. https://doi.org/10.2307/1913236

[19] Sargan, J.D. (1964) Wages and Prices in the United Kingdom: A Study in Econometric Methodology. In: Hart, P.E., Mills, G. and Whittaker, J.N., Eds., Econometric Analysis for National Economic Planning, Butterworths, London, 25-54.

[20] Jarque, C.M. and Bera, A.K. (1980) Efficient Tests for Normality, Homoscedasticity and Serial Independence of Regression Residuals. Economics Letters, 6, 255-259. https://doi.org/10.1016/0165-1765(80)90024-5

[21] Gujarati, D.N. and Porter, D.C. (2009) How to Measure Elasticity: The Log-Linear Model. In: Basic Econometrics, McGraw-Hill/Irwin, New York, 159-162.

[22] Ministry of Expatriates Welfare and Overseas Employment (2017). http://www.probashi.gov.bd/data

[23] World Bank (2017) World Bank Development Indicators. https://datacatalog.worldbank.org/dataset/worlddevelopmentindicators.Data

[24] Fred Economic Indicator (2018). https://fred.stlouisfed.org/search/indicator

[25] Godfrey, L.G. (1996) Misspecification Tests and Their Uses in Econometrics. Journal of Statistical Planning and Inference, 49, 241-260. https://doi.org/10.1016/0378-3758(95)00039-9

[26] Breusch, T.S. and Pagan, A.R. (1979) A Simple Test for Heteroskedasticity and Random Coefficient Variation. Econometrica, 47, 1287-1294. https://doi.org/10.2307/1911963

[27] Dickey, D.A. and Fuller, W.A. (1979) Distribution of the Estimators for Autoregressive Time Series with a Unit Root. Journal of the American Statistical Association, 74, 427-431. https://doi.org/10.1080/01621459.1979.10482531

[28] Akaike, H. (1974) A New Look at the Statistical Model Identification. IEEE Transactions on Automatic Control, 19, 716-723. https://doi.org/10.1109/TAC.1974.1100705

[29] Johansen, S. (1991) Estimation and Hypothesis Testing of Cointegration Vectors in Gaussian Vector Autoregressive Models. Econometrica, 59, 1551-1580. https://doi.org/10.2307/2938278 